\title{
Nitrogen addition alters elemental stoichiometry within soil aggregates in a temperate steppe
}

\author{
Jinfei Yin ${ }^{1,2}$, Ruzhen Wang ${ }^{1}$, Heyong Liu ${ }^{1}$, Xue Feng ${ }^{1}$, Zhuwen Xu ${ }^{1}$, and Yong Jiang ${ }^{1}$ \\ ${ }^{1}$ State Engineering Laboratory of Soil Nutrient Management, Institute of Applied Ecology, Chinese Academy \\ of Sciences, Shenyang 110016, China \\ ${ }^{2}$ University of Chinese Academy of Sciences, Beijing 100049, China \\ Correspondence to: Ruzhen Wang (ruzhenwang@iae.ac.cn)
}

Received: 5 September 2016 - Published in Solid Earth Discuss.: 12 September 2016

Revised: 1 November 2016 - Accepted: 9 November 2016 - Published: 23 November 2016

\begin{abstract}
Ongoing increases in anthropogenic nitrogen (N) inputs have largely affected soil carbon (C) and nutrient cycling in most terrestrial ecosystems. Numerous studies have concerned the effects of elevated $\mathrm{N}$ inputs on soil dissolved organic carbon (DOC), dissolved inorganic $\mathrm{N}$ (DIN), available phosphorus (AP), exchangeable calcium (Ca) and magnesium $(\mathrm{Mg})$, and available iron $(\mathrm{Fe})$ and manganese (Mn). However, few have emphasized the stoichiometric traits of these soil parameters, especially within different soil aggregate fractions. In a semiarid grassland of Inner Mongolia, we studied the effect of $\mathrm{N}$ addition on the ratios of DOC:DIN, DOC:AP, DIN : AP, exchangeable $\mathrm{Ca}: \mathrm{Mg}$, available $\mathrm{Fe}: \mathrm{Mn}$ within three soil aggregate classes of large macroaggregates $(>2000 \mu \mathrm{m})$, small macroaggregates $(250-2000 \mu \mathrm{m})$, and microaggregates $(<250 \mu \mathrm{m})$. Elevated $\mathrm{N}$ inputs significantly decreased the DOC:DIN ratio within three soil aggregates. The soil DOC: AP ratio significantly decreased along with increasing $\mathrm{N}$ gradients within large macroaggregates and microaggregates. Nitrogen significantly decreased the ratio of exchangeable $\mathrm{Ca}: \mathrm{Mg}$ within soil macroaggregates. The ratio of available Fe:Mn decreased with $\mathrm{N}$ addition within three soil aggregate classes. Alteration of elemental stoichiometry within soil fractions that are characterized by different nutrient retention capacity will influence the chemical composition of soil microorganisms and plant quality.
\end{abstract}

\section{Introduction}

The use of chemical fertilizers in agriculture is widespread today (Novara et al., 2016; Zupanc et al., 2016). This is resulting in environmental damages to the soil system as chemical fertilizers are part of the modernization of the agriculture around the world and trigger soil degradation and erosion (Cerdà et al., 2009; Ochoa-Cueva et al., 2015; Rodrigo Comino et al., 2016). Grasslands are one of the landscapes that need more attention to the impact of management (Lü et al., 2016; Pereira et al., 2016) as other agriculture landscapes are already well studied (Beniston et al., 2016; de Oliveira et al., 2015; Moreno et al., 2016). The abuse of nitrogen (N) in the agriculture fields is a well-known topic but little is known about its impacts on the grassland soil ecosystems (Liu et al., 2016; Zhang et al., 2016).

Stoichiometric relationships of soil nutrients are reliable indicators of nutrient availabilities for plants and soil microorganisms (Cleveland and Liptzin, 2007). Soil carbon: nitrogen:phosphorus $(\mathrm{C}: \mathrm{N}: \mathrm{P})$ ratios play essential roles in shaping plant and microbial stoichiometry, which reveals nutrient allocations, life history strategies, and physiological adjustment to climate change (Elser et al., 2010). For instance, enhanced $\mathrm{N}$ inputs resulted in higher soil $\mathrm{N}$ availability (Wei et al., 2013) and consequentially a decrease in foliar $\mathrm{C}: \mathrm{N}$ and an increase in the foliar $\mathrm{N}: \mathrm{P}$ ratio (Han et al., 2014). Nitrogen addition was suggested to cause divergent effects on the plant $\mathrm{C}: \mathrm{P}$ ratio, which declined at species level but showed no change at the community level (Han et al., 2014). Plant species that are stoichiometric $\mathrm{N}$ : P flexibility may have an advantage over those possessing strict stoi- 
chiometric homeostasis under environmental changes (Sardans and Peñuelas, 2012). Leaves with high nutrient concentrations (both $\mathrm{N}$ and $\mathrm{P}$ ), which are relatively lower $\mathrm{C}: \mathrm{N}$ and $\mathrm{C}: \mathrm{P}$ ratios, tend to be short lived, with a high specific leaf area (Wright et al., 2004) as well as a high photosynthetic capacity and dark respiration rates (Reich et al., 2008). Local nutrient availability from soils is suggested to be one of the most important contributors to the wide variation of terrestrial plants in $\mathrm{C}: \mathrm{N}: \mathrm{P}$ ratios (i.e., plants are what they root in; Elser et al., 2010). Soil exchangeable calcium (Ca) and magnesium $(\mathrm{Mg})$ and available iron $(\mathrm{Fe})$ and manganese $(\mathrm{Mn})$ are critical metal nutrients for plant growth, microbial activity, and ecosystem health (Lucas et al., 2011). The ratio of exchangeable $\mathrm{Ca}: \mathrm{Mg}$ indicates the relative availability of these two ions and is reported to influence clay dispersion and surface sealing processes (Dontsova and Norton, 2002). Maintaining a properly available $\mathrm{Fe}$ : Mn ratio is essential for plant health as a lower ratio might suggest plants suffering from Fe deficiency and Mn toxicity (Hodges, 2010). However, the stoichiometric qualification of soil DOC and available nutrients is less known than plant stoichiometry.

Ongoing increases in anthropogenic $\mathrm{N}$ inputs have largely affected soil $\mathrm{C}$ and nutrient cycles in most terrestrial ecosystems (Lü et al., 2013; Neff et al., 2002). Under N enrichment, higher soil available $\mathrm{N}$ (sum of nitrate and ammonium) has been documented to be positively (Wei et al., 2013), negatively (Heffernan and Fisher, 2012), or even neutrally (Liu and Greaver, 2010) related to dissolved organic C (DOC), which is an important linkage for plant-soil-microbe systems in natural ecosystems. Anthropogenic increases in reactive $\mathrm{N}$ would also shift ecosystem nutrient limitation from $\mathrm{N}$ to $\mathrm{P}$ by stimulating $\mathrm{P}$ uptake by plants (Menge and Field, 2007). Moreover, soil acidification caused by $\mathrm{N}$ enrichment could help desorption and dissolution of soil inorganic P, serving as an essential $P$ source for plants, especially in calcareous soils (Lajtha and Bloomer, 1988; Tunesi et al., 1999). Soil $\mathrm{pH}$ is widely recognized as one of the most influential factors that regulates nutrient bioavailability (Kemmitt et al., 2006). For example, Piccolo (2001) suggested that a drop in soil $\mathrm{pH}$ elevated the solubility of soil humic substances. Soil $\mathrm{pH}$ is also suggested to influence the soil $\mathrm{C}: \mathrm{N}$ ratio via changes in plant litter quality (Schmidt, 1982) and increase soil available $\mathrm{P}$ (AP) by promoting phosphomonoesterase activity (Hogan et al., 2010). Thus, $\mathrm{N}$ enrichment might influence soil available $\mathrm{C}: \mathrm{N}: \mathrm{P}$ stoichiometry through the alteration of soil $\mathrm{pH}$, and hence aggravate or alleviate plant and microbial C and nutrient limitations (Elser et al., 2010). Enhanced $\mathrm{N}$ inputs cause leaching of soil exchangeable $\mathrm{Ca}$ and $\mathrm{Mg}$ and activation of soil available $\mathrm{Fe}$ and $\mathrm{Mn}$ as a result of soil acidification, which will lead to nutrient imbalance in soils (Katou, 2002; Malhi et al., 1998). For example, $\mathrm{N}$ deposition decreases the ratio of exchangeable $\mathrm{Ca}: \mathrm{Mg}$ as preferential weathering of soil exchangeable $\mathrm{Ca}$ relative to $\mathrm{Mg}$ (Lu et al., 2014). Iron deficiency chlorosis has been found in calcareous soils in grasslands of America (Rogovska et al., 2007) and Mn toxicity may occur after soil acidification accompanying leaching of base cations (Lynch and Clair, 2004). Thus, the available $\mathrm{Fe}: \mathrm{Mn}$ ratio will be useful in indicating the relative availability of $\mathrm{Fe}$ and $\mathrm{Mn}$ as affected by $\mathrm{N}$ addition. Under anthropogenic $\mathrm{N}$ enrichment scenarios, clarifying stoichiometric traits of soil available elements would promote our understanding of soil nutrient imbalance as caused by environmental changes.

Physical protection by soil aggregation is a main mechanism of soil organic matter (SOM) stabilization (Amezketa, 1999; Wiesmeier et al., 2012). Oxygen and water diffusion rates are generally parallel with soil aggregate sizes as determined by pore space (Young and Ritz, 2000; Baker et al., 2007). Consequently, available nutrients like $\mathrm{N}$ and $\mathrm{P}$ tend to distribute in aggregates of larger size due to more favorable microclimates for microbial activity herein (Dorodnikov et al., 2009; Wu et al., 2012). Smaller aggregate-size classes are confirmed as a preferential site for the physical stabilization of SOM and nutrient retention (Fonte et al., 2014). Higher clay contents in microaggregates tend to provide more surface area and binding sites to retain more exchangeable $\mathrm{Ca}$ and $\mathrm{Mg}$ (Oorts et al., 2003). Within microaggregates, more microbial-processed SOM will also chelate or make complex a larger amount of base cations and micronutrients (Lü et al., 2016). Even though numerous studies have focused on $C$ and nutrient cycling in the aggregate scale (Fonte et al., 2014; Six and Paustian, 2014; Wright, 2009), stoichiometric traits of DOC and available nutrients within aggregates are still unclear.

Semiarid steppes of Inner Mongolia in northern China, playing a vital role in serving environmental health, regional economy, and the global $\mathrm{C}$ cycle, have undergone degradation during the last 50 years' increased stocking rates and static grazing management practices (Kang et al., 2007). Non-physically protected SOM pools, which can be a majority of SOC and nutrients in these sandy grassland systems, are, however, inherently vulnerable to environmental changes (Creamer et al., 2011), like elevated $\mathrm{N}$ inputs. A 7 -year $\mathrm{N}$ field manipulation experiment has already shown significant aboveground changes in species turnover rates, plant community composition, and community stability (Xu et al., 2012). Microaggregates $(<250 \mu \mathrm{m})$ had the highest dissolved inorganic $\mathrm{N}$ (DIN) concentration as compared to large (> $2000 \mu \mathrm{m})$ and small $(250-2000 \mu \mathrm{m}$; see Wang et al., 2015a) macroaggregates, which was not the case for both DOC (see Wang et al., 2015b) and AP (Wang et al., 2016a). Nitrogen addition significantly increased DIN (see Wang et al., 2015a) and available $\mathrm{Fe}$ and $\mathrm{Mn}$ but decreased exchangeable $\mathrm{Ca}$ and $\mathrm{Mg}$ across three soil fractions (not for $\mathrm{Ca}$ in $\mathrm{mi}-$ croaggregates; Wang et al., 2016b). In this study, we aimed to analyze stoichiometric traits of DOC, DIN, AP, exchangeable $\mathrm{Ca}$ and $\mathrm{Mg}$, and available $\mathrm{Fe}$ and $\mathrm{Mn}$ within soil aggregates in this semiarid grassland. We hypothesize that microaggregates had lower DOC:DIN and higher DIN : AP ratios due to better $\mathrm{N}$ retention capacity in smaller-size aggregates. We 


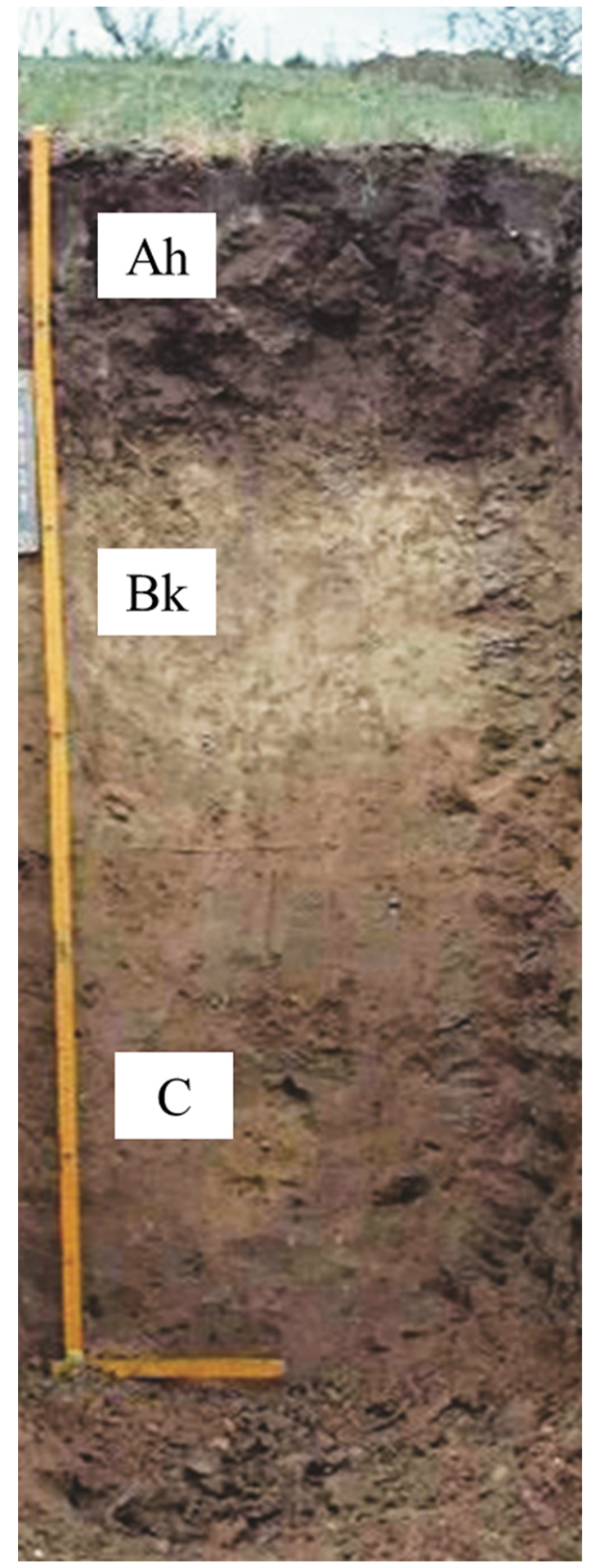

Figure 1. Schematic diagram of chestnut soil illustrating three soil horizons (figure modified from the Digital Science and Technology Museum of China, http://amuseum.cdstm.cn/AMuseum/agricul/6_ 5_27_ligt.html). also hypothesized that $\mathrm{N}$ addition would decrease DOC : DIN while increasing DOC : AP and DIN : AP ratios due to higher anthropogenic inputs of inorganic $\mathrm{N}$ and intensive removal of available $\mathrm{P}$ from soil by plant uptake. Due to preferential weathering of $\mathrm{Ca}$ relative to $\mathrm{Mg}$ during soil acidification, we expected to detect a significant decrease in the $\mathrm{Ca}: \mathrm{Mg}$ ratio under $\mathrm{N}$ addition across soil aggregate classes. Due to the fact that plant growth is commonly limited by Fe deficiency in calcareous grasslands, enhanced Fe translocation from soil to plants would result in a lower soil available $\mathrm{Fe}$ : Mn ratio under $\mathrm{N}$ enrichment.

\section{Methods}

\subsection{Study site and experimental design}

The study site $\left(42^{\circ} 02^{\prime} 27^{\prime \prime} \mathrm{N}, 116^{\circ} 17^{\prime} 59^{\prime \prime} \mathrm{E}\right.$, elevation 1324 m a.s.l.) was located in Duolun County, a semiarid area in Inner Mongolia, China. The mean annual temperature is $2.1^{\circ} \mathrm{C}$, ranging from $17.8^{\circ} \mathrm{C}$ in January to $18.8^{\circ} \mathrm{C}$ in July, and average precipitation is $379.4 \mathrm{~mm} \mathrm{yr}^{-1}$. The soil is chestnut in the Chinese classification and Calcisorthic Aridisol in the US Soil Taxonomy classification. The soil texture of the experimental site is sandy loam with $62.75 \%$ sand, $20.30 \%$ silt, and $16.95 \%$ clay (Liu et al., 2009). The soil contains an Ah horizon of $25-50 \mathrm{~cm}$ thickness with dark brown color, a $\mathrm{Bk}$ horizon of $30-50 \mathrm{~cm}$ thickness with grayish color, and a $\mathrm{C}$ horizon with dark-grayish brown color (Fig. 1; Heil and Buntley, 1965; Buol et al., 2011).

In April 2005, seven blocks $(107 \mathrm{~m} \times 8 \mathrm{~m})$ were set up in a split-plot design with water and $\mathrm{N}$ being the two treatments. Each block was divided into two main plots receiving either ambient precipitation or additional water treatment $(180 \mathrm{~mm})$. Each main plot was divided into six subplots which were randomly treated with four levels of $\mathrm{N}$ $\left(0[\mathrm{CK}], 5\left[\mathrm{~N}_{5}\right], 10\left[\mathrm{~N}_{10}\right]\right.$, and $\left.15\left[\mathrm{~N}_{15}\right] \mathrm{g} \mathrm{N} \mathrm{m}^{-2} \mathrm{yr}^{-1}\right), \mathrm{P}$ $\left(10 \mathrm{~g} \mathrm{~N} \mathrm{~m}^{-2} \mathrm{yr}^{-1}\right)$, and combined $\mathrm{N}$ and $\mathrm{P}$ addition. This study was only concerned about the treatments of four levels of $\mathrm{N}$ addition under ambient precipitation. Nitrogen was added as urea pellets, with half of it applied in early May and the other half in late June.

\subsection{Field sampling and measurements}

Soil samples $(0-10 \mathrm{~cm})$ were collected from each $\mathrm{N}$ plot from four out of seven blocks in August 2013. For each plot, five random cores were retrieved after removing the litter layer and stored at $4^{\circ} \mathrm{C}$ under further analysis. Soil aggregates were isolated according to Dorodnikov et al. (2009) into three aggregates $(>2000 \mu \mathrm{m}$, large macroaggregate class; $250-2000 \mu \mathrm{m}$, small macroaggregates; and $<250 \mu \mathrm{m}$, microaggregate class) by a Retsch AS 200 Control (Retsch Technology, Düsseldorf, Germany). This dry-sieving method was used to maintain microbial activity and reduce the loss of DOC and available nutrients in soil aggregates. The sepa- 
Table 1. The concentrations of soil organic carbon (SOC, $\mathrm{g} \mathrm{kg}$ soil aggregate ${ }^{-1}$ ), total nitrogen $\left(\mathrm{g} \mathrm{kg}\right.$ soil aggregate $^{-1}$ ), dissolved organic carbon (DOC, $\mathrm{mg} \mathrm{kg}$ soil aggregate ${ }^{-1}$ ), dissolved inorganic nitrogen (DIN, mg kg soil aggregate ${ }^{-1}$ ), available phosphorus (AP, mgkg soil aggregate ${ }^{-1}$ ), exchangeable $\mathrm{Ca}$ and $\mathrm{Mg}$ (cmol kg soil aggregate $\left.{ }^{-1}\right)$, and available $\mathrm{Fe}$ and $\mathrm{Mn}$ (mg kg soil aggregate ${ }^{-1}$ ) within bulk soil and soil fractions of $0-10 \mathrm{~cm}$ soils without field-manipulated treatments (data from Wang et al., 2015a, b, and 2016a).

\begin{tabular}{lrrrr}
\hline & & \multicolumn{3}{c}{ Soil aggregates $(\mu \mathrm{m})$} \\
\cline { 3 - 5 } & Bulk soil & $>2000$ & $250-2000$ & $<250$ \\
\hline SOC & $18.9 \pm 1.7$ & $18.2 \pm 1.0$ & $15.1 \pm 2.0$ & $21.6 \pm 1.4$ \\
TN & $1.8 \pm 0.2$ & $1.9 \pm 0.1$ & $1.5 \pm 0.2$ & $2.2 \pm 0.1$ \\
DOC & $69.8 \pm 5.6$ & $72.5 \pm 6.8$ & $66.6 \pm 1.3$ & $71.2 \pm 1.5$ \\
DIN & $21.6 \pm 1.5$ & $21.1 \pm 0.6$ & $49.5 \pm 1.9$ & $57.3 \pm 2.0$ \\
AP & $14.9 \pm 2.8$ & $3.7 \pm 0.4$ & $5.8 \pm 0.7$ & $3.9 \pm 0.5$ \\
Ca & $19.6 \pm 0.3$ & $26.6 \pm 0.7$ & $19.8 \pm 0.4$ & $22.7 \pm 2.7$ \\
$\mathrm{Mg}$ & $1.7 \pm 0.05$ & $1.8 \pm 0.1$ & $1.4 \pm 0.05$ & $2.0 \pm 0.1$ \\
$\mathrm{Fe}$ & $21.8 \pm 0.6$ & $24.0 \pm 1.8$ & $20.0 \pm 1.4$ & $27.5 \pm 2.8$ \\
$\mathrm{Mn}$ & $23.3 \pm 2.7$ & $24.5 \pm 0.8$ & $20.0 \pm 0.8$ & $24.0 \pm 1.9$ \\
\hline
\end{tabular}

rated aggregates were weighed and used for determining soil aggregate moisture (drying at $105^{\circ} \mathrm{C}$ for $48 \mathrm{~h}$ ), DOC, DIN, $\mathrm{AP}$, exchangeable $\mathrm{Ca}$ and $\mathrm{Mg}$, and available $\mathrm{Fe}$ and $\mathrm{Mn}$.

Soil $\mathrm{pH}$ was measured in a $1: 2.5(w / v)$ soil-to-water slurry of soil aggregate samples with a digital $\mathrm{pH}$ meter. The concentration of DOC was extracted by adding $50 \mathrm{~mL}$ of $0.5 \mathrm{M}$ potassium sulfate and analyzed by a TOC analyzer (High TOC, Elementar). Soil DIN concentration was extracted with $50 \mathrm{~mL} 2 \mathrm{M} \mathrm{KCl}$ from $10 \mathrm{~g}$ fresh soils (McLeod, 1992) and determined colorimetrically using an AutoAnalyser III continuous Flow Analyzer (Bran \& Luebbe, Norderstedt, Germany). Soil AP was measured using the Olsen method (Olsen et al., 1954). Briefly, $2.5 \mathrm{~g}$ of the soil fraction was mixed with $50 \mathrm{~mL} 0.5 \mathrm{M} \mathrm{NaHCO}_{3}(\mathrm{pH} 8.5)$ and $5 \mathrm{~g}$ of phosphorus-free charcoal. The mixture was shaken at $150 \mathrm{rpm}$ for $30 \mathrm{~min}$ and filtered. The $\mathrm{P}$ concentration of $\mathrm{P}$ in filtration was determined by the molybdenum blue colorimetric method (Murphy and Riley, 1962). The units of DOC, DIN, and AP were expressed in $\mathrm{mg}$ per kg soil aggregate. Exchangeable $\mathrm{Ca}$ and $\mathrm{Mg}$ within soil aggregates were extracted by mixing a $2.5 \mathrm{~g}$ soil fraction with $50 \mathrm{~mL} 1 \mathrm{M}$ ammonium acetate (pH 7.0) and then shaken for $30 \mathrm{~min}$ at $150 \mathrm{rpm}$. After filtration, the $\mathrm{Ca}$ and $\mathrm{Mg}$ concentrations in extraction were determined by an atomic absorption spectrometer (AAS, Shimadzu, Japan). To analyze available Fe and Mn within soil aggregate fractions, $10 \mathrm{~g}$ of soil samples were extracted by $20 \mathrm{~mL} 0.005 \mathrm{M}$ DTPA $+0.01 \mathrm{M} \mathrm{CaCl}_{2}+0.1 \mathrm{M}$ TEA (triethanolamine; $\mathrm{pH}$ 7.0). After being shaken at $180 \mathrm{rpm}$ for $2 \mathrm{~h}$, the extracts were filtered and available $\mathrm{Fe}$ and $\mathrm{Mn}$ concentrations in the filtration were determined by the AAS. Soil DOC and available nutrients of the control plot were listed in Table 1 (data from Wang et al., 2015a, b, and 2016a). The
Table 2. Two-way ANOVAs ( $F$ values) of the effect of soil aggregate size $(\mathrm{S})$, nitrogen addition $(\mathrm{N})$, and their interactions on the ratios of DOC: DIN, DOC : AP, DIN : AP, exchangeable $\mathrm{Ca}: \mathrm{Mg}$, and available $\mathrm{Fe}: \mathrm{Mn}$.

\begin{tabular}{lrrrrr}
\hline & DOC : DIN & DOC : AP & DIN : AP & Ca $: \mathrm{Mg}$ & $\mathrm{Fe}: \mathrm{Mn}$ \\
\hline $\mathrm{S}$ & $100.86^{* *}$ & 0.41 & $16.32^{* *}$ & 1.81 & 0.25 \\
$\mathrm{~N}$ & $36.91^{* *}$ & $3.44^{*}$ & 1.73 & 1.19 & $109.23^{* *}$ \\
$\mathrm{~N} \times \mathrm{S}$ & $12.64^{* *}$ & 1.72 & $2.43^{*}$ & 2.07 & $7.41^{* *}$ \\
\hline
\end{tabular}

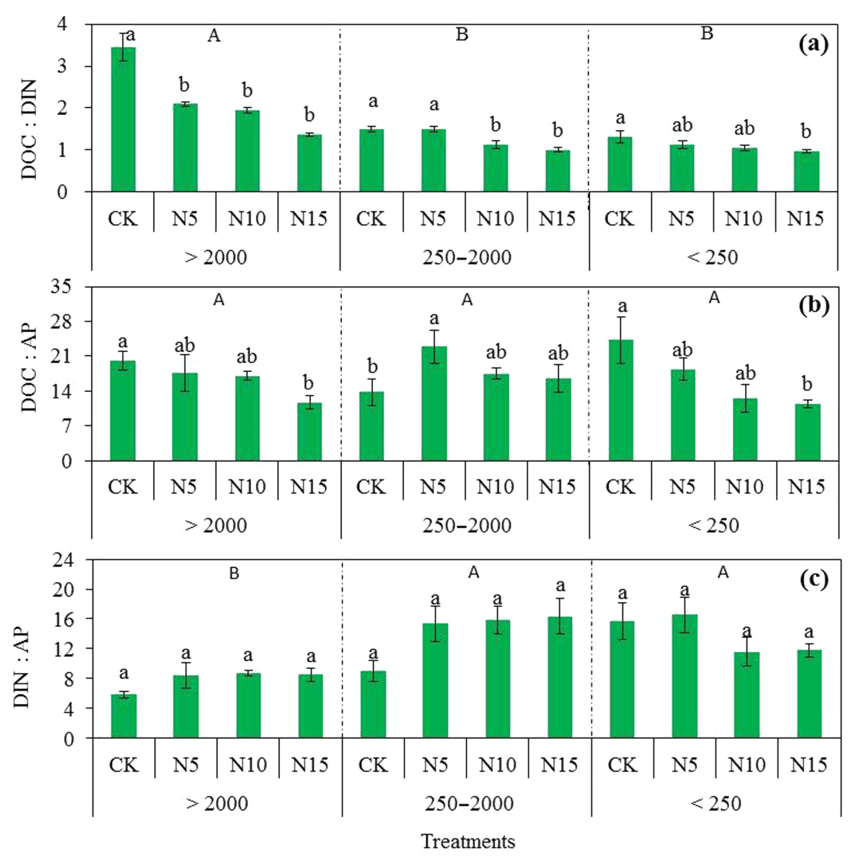

Figure 2. The ratio of (a) dissolved organic carbon to dissolved inorganic nitrogen (DOC: DIN), (b) DOC to available phosphorus (DOC : AP), and (c) DIN : AP as influenced by $\mathrm{N}$ addition (0 [CK], $5\left[\mathrm{~N}_{5}\right], 10\left[\mathrm{~N}_{10}\right]$, and $\left.15\left[\mathrm{~N}_{15}\right] \mathrm{g} \mathrm{N} \mathrm{m}^{-2} \mathrm{yr}^{-1}\right)$ in soil aggregates. Data are represented as mean $\pm \mathrm{SE}$. Lowercase letters indicate significant differences between $\mathrm{N}$ treatments within a soil fraction. The capital letters at the top indicate significant differences between soil aggregate sizes across $\mathrm{N}$ treatments.

concentrations of exchangeable $\mathrm{Ca}$ and $\mathrm{Mg}$ were represented as cmol per $\mathrm{kg}$ soil aggregate, and it was a mg per $\mathrm{kg}$ soil aggregate for available Fe and Mn.

\subsection{Statistical analysis}

The normality of data and homogeneity of variances were determined by the Kolmogorov-Smirnov test and Levene's test, respectively. Two-way ANOVAs were executed to determine soil aggregate size (S), $\mathrm{N}$ addition, and their interactive effects $(\mathrm{S} \times \mathrm{N})$ on the ratios of DOC : DIN, DOC : AP, DIN : AP, exchangeable $\mathrm{Ca}: \mathrm{Mg}$, and available Fe : Mn. Multiple comparisons with a Duncan design were conducted to determine the difference between $\mathrm{N}$ treatments within each 


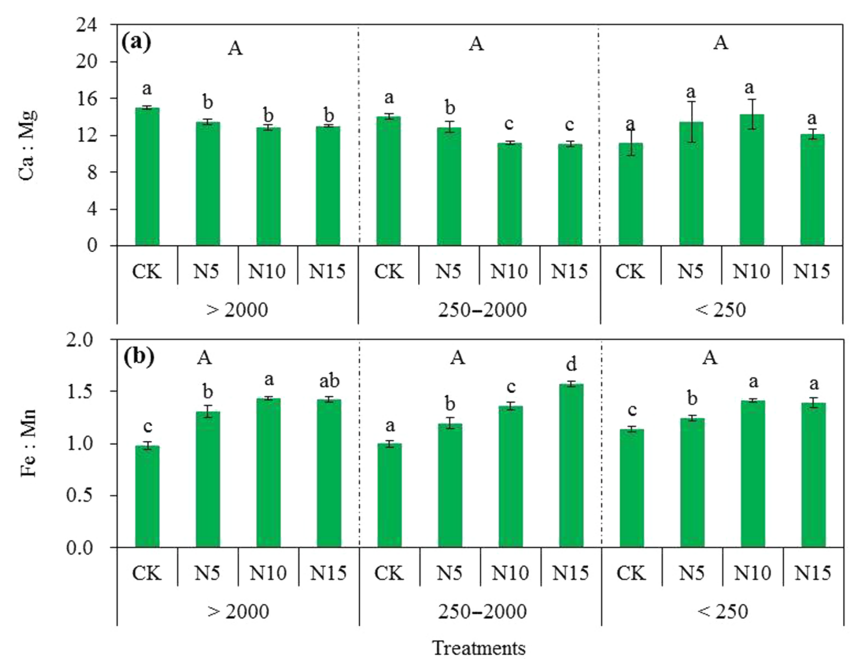

Figure 3. The ratio of (a) exchangeable $\mathrm{Ca}: \mathrm{Mg}$ and (b) available $\mathrm{Fe}: \mathrm{Mn}$ as influenced by $\mathrm{N}$ addition (0 [CK], $5\left[\mathrm{~N}_{5}\right], 10\left[\mathrm{~N}_{10}\right]$, and $\left.15\left[\mathrm{~N}_{15}\right] \mathrm{g} \mathrm{N} \mathrm{m}^{-2} \mathrm{yr}^{-1}\right)$ in soil aggregates. Data are represented as mean $\pm \mathrm{SE}$. Lowercase letters indicate significant differences between $\mathrm{N}$ treatments within a soil fraction. The capital letters at the top indicate significant differences between soil aggregate sizes across $\mathrm{N}$ treatments.

soil fraction. Pearson correlation analysis was used to determine the relationship between soil $\mathrm{pH}$ and these ratios within each soil aggregate class. The whole correlation analysis was performed in SPSS 16.0 (SPSS, Inc., Chicago, IL, USA) and statistical significance was accepted at $P<0.05$.

\section{Results}

\section{1 $\mathrm{N}$ addition effects on soil available $\mathrm{C}: \mathrm{N}: \mathrm{P}$}

The ratio of DOC:DIN varied from 1.4 to 3.4 within large macroaggregates, from 1.0 to 1.5 within small macroaggregates, and from 1.0 to 1.3 within microaggregates (Fig. 2a). The DOC:DIN ratio was significantly higher in large macroaggregates than in both small macroaggregates and microaggregates, averaging across all $\mathrm{N}$ treatments (Fig. 2a). Compared to CK, the DOC:DIN ratio was significantly lower in $\mathrm{N}_{5}, \mathrm{~N}_{10}$, and $\mathrm{N}_{15}$ treatments of large macroaggregates, in $\mathrm{N}_{10}$ and $\mathrm{N}_{15}$ of small macroaggregates, and in $\mathrm{N}_{15}$ of microaggregates (Fig. 2a). The DOC: DIN ratio significantly decreased under $\mathrm{N}_{5}$ and $\mathrm{N}_{10}$ treatments in large macroaggregates, but not for $\mathrm{N}_{5}$ in small macroaggregates and $\mathrm{N}_{5}$ and $\mathrm{N}_{10}$ in microaggregates, resulting in a significant interaction between $\mathrm{N}$ and aggregate size $(\mathrm{S} ; \mathrm{N} \times \mathrm{S}$; Table 2$)$.

No difference in the soil DOC: AP ratio was found among three aggregate classes (Fig. 2b). The soil DOC: AP ratio significantly decreased under $\mathrm{N}_{15}$ treatment in both large macroaggregates and microaggregates, but it increased under $\mathrm{N}_{5}$ in small macroaggregates (Fig. 2b). No significant interactive $\mathrm{N} \times \mathrm{S}$ was detected in the DOC: AP ratio (Table 2).
The DIN:AP ratio was significantly lower in large macroaggregates as compared to both small macroaggregates and microaggregates (Fig. 2c). The soil DIN : AP ratio showed no change along $\mathrm{N}$ gradients as compared to $\mathrm{CK}$ within three soil aggregates (Fig. 2c). There was a significant interaction of $\mathrm{N} \times \mathrm{S}$ in the DIN : AP ratio (Table 2).

\subsection{Nitrogen addition effects on exchangeable $\mathrm{Ca}: \mathrm{Mg}$ and available $\mathrm{Fe}: \mathrm{Mn}$ ratios}

The exchangeable $\mathrm{Ca}: \mathrm{Mg}$ ratio ranged from 11.0 to 15.0 across soil aggregate classes (Fig. 3a). Nitrogen addition significantly decreased the $\mathrm{Ca}: \mathrm{Mg}$ ratio compared to $\mathrm{CK}$ within large and small macroaggregates (Fig. 3a). Neither aggregate size nor interactive $\mathrm{N}$ and aggregate size effects were detected in changes in the $\mathrm{Ca}: \mathrm{Mg}$ ratio.

The ratio of available $\mathrm{Fe}: \mathrm{Mn}$ ranged from 0.98 to 1.57 across three soil aggregate fractions (Fig. 3b). No difference in the $\mathrm{Fe}: \mathrm{Mn}$ ratio was detected among three soil fractions (Fig. 3b, Table 2). Nitrogen addition significantly increased soil available Fe:Mn within three soil fractions (Fig. 3b). Nitrogen addition significantly interacted with soil aggregate size to affect the ratio of available Fe : Mn (Table 2).

\subsection{Correlation analyses}

The DOC: DIN ratio was positively correlated with soil $\mathrm{pH}$ within three soil fractions (Fig. 4a, b, c). A significantly positive relationship was found between the DOC: AP ratio and soil $\mathrm{pH}$ within large macroaggregates and microaggregates (Fig. 4d, f). A significant and negative correlation between the DIN : AP ratio and soil $\mathrm{pH}$ was only detected in small macroaggregates (Fig. 4h). Within large and small macroaggregates, the $\mathrm{Ca}: \mathrm{Mg}$ ratio was significantly and positively correlated with soil $\mathrm{pH}$ (Fig. 5a, b). Significant and negative relationships between the $\mathrm{Fe}: \mathrm{Mn}$ ratio and soil $\mathrm{pH}$ were found within three soil fractions (Fig. 5d, e, f).

\section{Discussion}

\subsection{The stoichiometric ratios among different soil aggregates fractions}

Consistent with our initial hypothesis, microaggregates had lower DOC : DIN ratios and higher DIN : AP ratios relative to large macroaggregates. It is generally recognized that more labile SOM concentrates in macroaggregates, with more recalcitrant SOM in microaggregates (Jastrow et al., 2007). Additionally, SOM in microaggregates experiences more microbial processing cycles which are more decomposed as compared to macroaggregates (Six and Paustian, 2014). These resulted in a lower $\mathrm{C}: \mathrm{N}$ of SOM in microaggregates. Our previous study suggested that microaggregates retained significantly higher inorganic $\mathrm{N}$ relative to large macroaggregates (Wang et al., 2015a). However, DOC and AP con- 

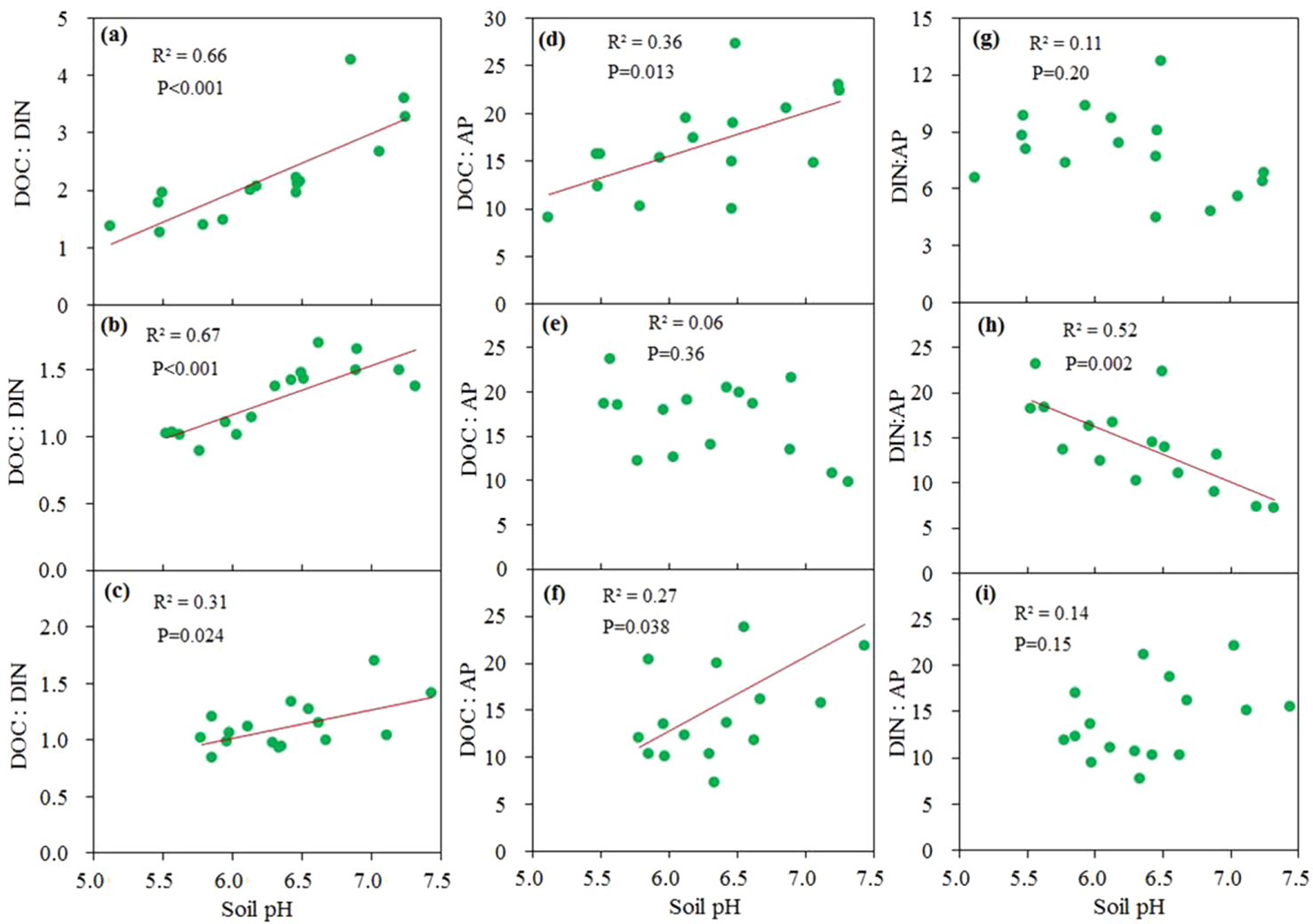

Figure 4. The relationships between soil $\mathrm{pH}$ and DOC : DIN within large macroaggregates (a), small macroaggregates (b), and microaggregates (c), between soil $\mathrm{pH}$ and DOC : AP within large macroaggregates (d), small macroaggregates (e), and microaggregates (f), and between soil $\mathrm{pH}$ and the DIN : AP ratio within large macroaggregates (g), small macroaggregates (h), and microaggregates (i). The significance level was set at $P<0.05$.

centrations showed no difference between large macroaggregates and microaggregates, as suggested by our previous studies (Wang et al., 2015b, 2016a). In this context, microaggregates had significantly lower DOC:DIN ratios (Fig. 2a) but higher DIN : AP ratios (Fig. 2c) than large macroaggregates. Our results indicated that microaggregates were preferential sites for retaining DIN relative to DOC and AP as compared to large macroaggregates (Fig. 2a,c). Microaggregates serve as an indicator of soil C storage capacity and help elucidate the capacity of soils to protect SOM and supply N and P nutrients (Du et al., 2015). Higher DIN : AP ratios in microaggregates would be essential for available $\mathrm{N}$ supply, but it might eventually result in $\mathrm{P}$ deficiency under enhanced $\mathrm{N}$ loading rates in the long term.

\subsection{Effect of $\mathrm{N}$ addition on DOC : DIN, DOC : AP, and DIN : AP ratios within soil aggregates}

As expected, we observed a significant decrease in the soil DOC : DIN ratio within all soil aggregate classes affected by $\mathrm{N}$ addition (Fig. 2a). This should mainly be due to a supply of DIN which is directly transformed from urea fertilizer or indirectly derived from enhanced soil organic $\mathrm{N}$ mineralization and nitrification under urea addition (Chen et al., 2013) within three soil fractions. Indeed, our previous studies suggested that $\mathrm{N}$ addition increased DIN by up to $128.3,41.2$, and $45.7 \%$ (Wang et al., 2015a), while DOC only increased by $12.7,3.7$, and $12.7 \%$ within large macroaggregates, small macroaggregates, and microaggregates, respectively (Wang et al., 2015b). As suggested by our previous work, $\mathrm{N}$ addition decreased soil $\mathrm{pH}$ from 7.3 to 5.6 in large macroaggregates, from 7.5 to 5.8 in small macroaggregates, and from 7.4 to 5.9 in microaggregates (Wang et al., 2015b). Soil pH was one of the main factors influencing the DOC:DIN ratio, as suggested by their positive correlations within three soil fractions (Fig. 4a, b, c). A decline in soil pH was reported to be associated with accumulation of soil DIN (Aciego Pietri and Brooks, 2008), thus leading to the decrease in the DOC: DIN ratio (Fig. 3a, b, c).

Soil DOC and DIN are important energy and N sources for microorganisms, and relative soil $\mathrm{C}$ and $\mathrm{N}$ availabilities (represented as DOC:DIN) make a great contribution to controlling microbial activity and nutrient cycling processes (Dijkstra et al., 2006; Wu et al., 2012). A significant decrease in DOC: DIN (Fig. 1a) might suggest that higher $\mathrm{N}$ inputs induced microbial $\mathrm{C}$ limitation relative to $\mathrm{N}$ across soil fractions. However, Wei et al. (2013) found that $\mathrm{N}$ ad- 

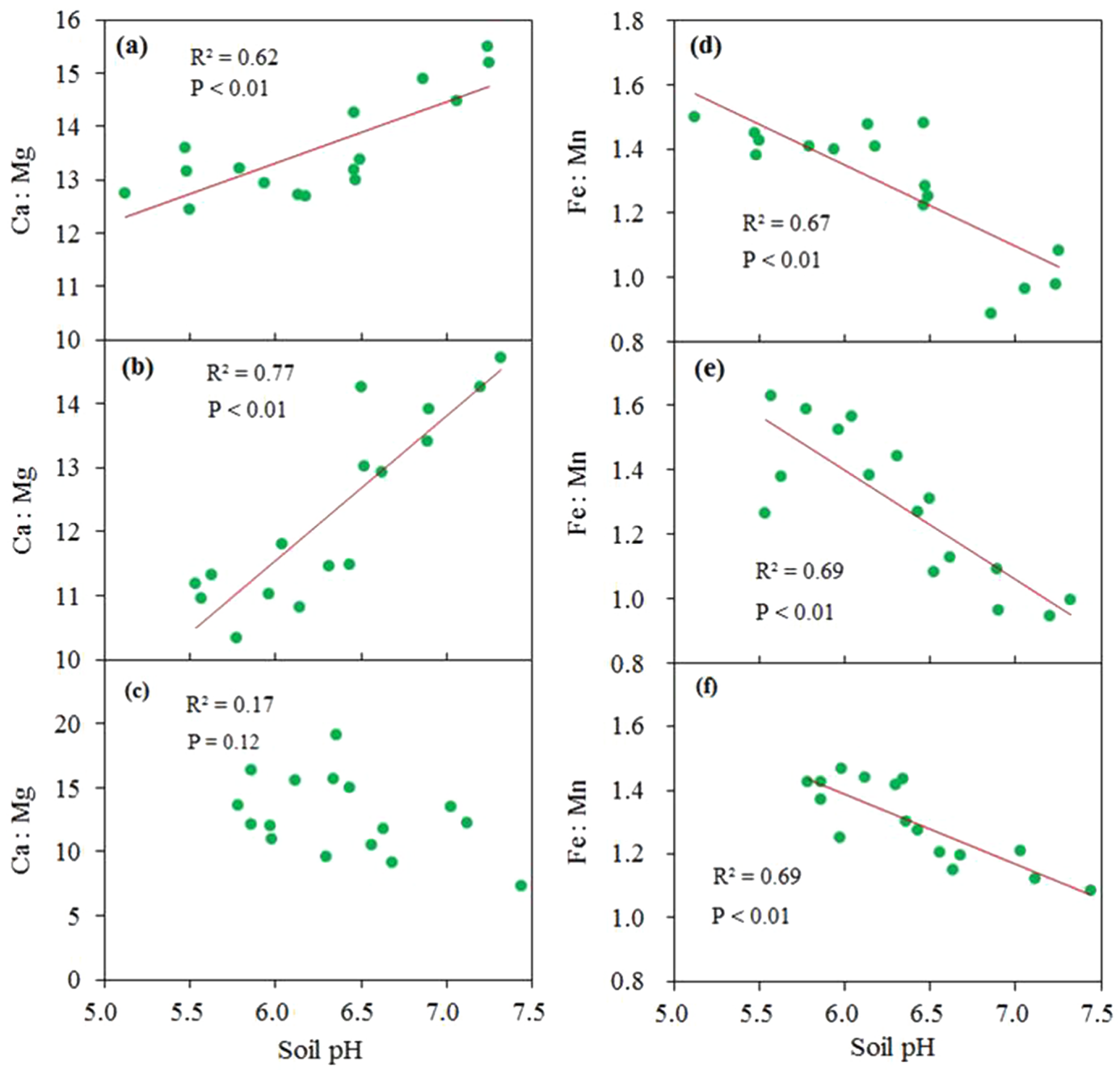

Figure 5. The relationships between soil $\mathrm{pH}$ and exchangeable $\mathrm{Ca}: \mathrm{Mg}$ within large macroaggregates (a), small macroaggregates (b), and microaggregates (c), and between soil $\mathrm{pH}$ and the available $\mathrm{Fe}: \mathrm{Mn}$ ratio within large macroaggregates (d), small macroaggregates (e), and microaggregates (f). The significance level was set at $P<0.05$.

dition increased both DOC and DIN but decreased microbial biomass $\mathrm{C}(\mathrm{MBC})$ concentration, and they suggested that soil microbes were no longer $\mathrm{C}$-limited due to a non-significant correlation between DOC and microbial biomass C. In their study, they failed to analyze the relationship between the DOC: DIN ratio and MBC, which could be used to indicate relative $\mathrm{C}$ and $\mathrm{N}$ availabilities in determining microbial growth. In this study, a coincident decrease in the DOC: DIN ratio (Fig. 2a) and MBC (see Wang et al., 2015b) indicated that repression of microbial growth under $\mathrm{N}$ addition was due to lower C availability relative to $\mathrm{N}$ (Treseder, 2008).

Our previous study suggested that $\mathrm{N}$ addition increased soil AP by 60.2 and $84.5 \%$ within large macroaggregates and microaggregates, respectively (Wang et al., 2016a). Based on this, it was reasonable to detect a significant decrease in the ratio of DOC: AP within large macroaggregates and microaggregates (Fig. 2b). Soil acidification could enhance dis- solution of phosphate from mineral-bound P pools, while this was not the case for DOC (Wang et al., 2016a). Thus, production of DOC might not keep up with continuous dissolution of $\mathrm{AP}$, resulting in a lower DOC: $\mathrm{AP}$ ratio under $\mathrm{N}$ addition (Fig. 2b). Significant positive correlations between soil $\mathrm{pH}$ and the DOC : AP ratio (Fig. 4d, f) also confirmed higher AP dissolution than DOC supply under soil acidification. Under the scenario of enhanced ecosystem $\mathrm{N}$ inputs, a decrease in the soil aggregate DOC: AP ratio would induce microbial C limitation relative to $\mathrm{P}$ (Treseder, 2008), and continuous release of AP from rock weathering would shift the ecosystem from $\mathrm{N}$ limitation to $\mathrm{P}$ limitation in the long term (Lü et al., 2013). 


\subsection{Effect of $\mathrm{N}$ addition on exchangeable $\mathrm{Ca}: \mathrm{Mg}$ and available $\mathrm{Fe}: \mathrm{Mn}$ ratios}

Within large and small macroaggregates, a significant decrease in the exchangeable $\mathrm{Ca}: \mathrm{Mg}$ ratio supported our hypothesis. Soil acidification, as developed under increased $\mathrm{SO}_{2}$ and $\mathrm{NO}_{x}$ emissions, results in weathering and release of base cations (Lucas et al., 2011). Selective weathering of certain base cations $(\mathrm{Ca}>\mathrm{Na}>\mathrm{Mg}>\mathrm{K})$ would result in a change in base cation budgets and an imbalance of metal ions in soils (Lu et al., 2014). Preferential loss of exchangeable $\mathrm{Ca}$ relative to $\mathrm{Mg}$ was the main reason for the significant decrease in the $\mathrm{Ca}: \mathrm{Mg}$ ratio in large and small macroaggregates (Fig. 3a). Correlation analyses also suggested a coincident decline in the $\mathrm{Ca}: \mathrm{Mg}$ ratio and soil $\mathrm{pH}$, indicating that more exchangeable $\mathrm{Ca}$ was leached than $\mathrm{Mg}$ during soil acidification in macroaggregates. However, the unaffected $\mathrm{Ca}: \mathrm{Mg}$ ratio in microaggregates contradicted our hypothesis that the $\mathrm{Ca}: \mathrm{Mg}$ ratio would decrease across three soil fractions. In this sandy grassland, microaggregates containing more minerals and less sand would be a more favorable site for base cation binding and adsorption, which was less affected by $\mathrm{N}$ addition and sequential soil acidification compared to macroaggregates (Gunina and Kuzyakov, 2014). Moreover, more decomposed SOM as indicated by $\delta^{13} \mathrm{C}$ (Wang et al., 2015a) would provide an additional strong binding surface for exchangeable $\mathrm{Ca}$ and $\mathrm{Mg}$ in microaggregates. Thus, a significant relationship of the $\mathrm{Ca}: \mathrm{Mg}$ ratio with soil $\mathrm{pH}$ was not detected in microaggregates (Fig. 5c).

The soil $\mathrm{Ca}: \mathrm{Mg}$ ratio affects plant $\mathrm{Cu}$ uptake and lower $\mathrm{Ca}: \mathrm{Mg}$ might increase or decrease plant $\mathrm{Cu}$ uptake and toxicity depending on plant species and soil types (Lombini et al., 2003). Under enhanced $\mathrm{N}$ inputs, a significant decrease in the $\mathrm{Ca}: \mathrm{Mg}$ ratio would further influence nutrient balance, i.e., $\mathrm{Cu}$ uptake of plants in this calcareous grassland. Researchers proposed that relative availabilities of exchangeable $\mathrm{Ca}$ and $\mathrm{Mg}$ were more important than their absolute amounts (Bear et al., 1951; Albrecht, 1975; Kopittke and Menzies, 2007), and optimal Ca: Mg ratio ranges for plant growth were identified for various plant species since the study from Loew (1892). In addition, different soil aggregate classes were characterized by their various nutrient supply capacities (Mikha and Rice, 2004). Soil structure could modify the effect of cation ratios on plant growth (Zhang and Norton, 2002). These shed light on the essential role of studying the soil exchangeable $\mathrm{Ca}: \mathrm{Mg}$ ratio of different soil aggregate fractions in evaluating soil fertility and plant growth.

For all soil fractions, a significant increase in the available $\mathrm{Fe}: \mathrm{Mn}$ ratio contradicted our initial hypothesis. A decrease in the $\mathrm{Fe}: \mathrm{Mn}$ ratio might be caused by the antagonistic relationship between $\mathrm{Fe}$ and Mn during plant uptake (Somers and Shive, 1942). Soil acidification promoted weathering and desorption of micronutrients from soil minerals, which increased soil available $\mathrm{Fe}$ and $\mathrm{Mn}$ concentrations (Malhi et al., 1998). Even though $\mathrm{Fe}$ availability generally limits pro- ductivity in calcareous grasslands, enhanced plant Mn uptake might retard plant $\mathrm{Fe}$ acquisition, leading to higher available Fe retained in soil (Tanaka and Navasero, 1966; Tian et al., 2016) under soil acidification. Correspondingly, negative relationships of soil $\mathrm{pH}$ with $\mathrm{Fe}$ : $\mathrm{Mn}$ ratios (Fig. 5d, e, f) suggested accumulation of available Fe relative to Mn under soil acidification as affected by enhanced $\mathrm{N}$ inputs. Consistent with our findings, Tian et al. $(2015,2016)$ found soil acidification enhanced $\mathrm{Mn}$ uptake and reduced $\mathrm{Fe}$ absorption by forbs which result in lower photosynthetic rates and growth and loss of forb species. Plant Fe deficiency was reported to induce chlorosis and decrease photosynthesis in calcareous grassland (Rogovska et al., 2007). An increase in the soil available $\mathrm{Fe}: \mathrm{Mn}$ ratio might pose a threat to grassland productivity such as potential aggravation of Fe deficiency and the occurrence of Mn toxicity to plant species (Tian et al., 2016). Soil nutrient imbalance would not only influence both the quantity (yield) and quality of plants, but also cause an impact on the health of animals grazing on these plants (Mikha and Rice, 2004).

\section{Conclusions}

After 9-year $\mathrm{N}$ amendment, we found that microaggregates had lower DOC: DIN but higher DIN : AP ratios. The soil DOC : DIN ratio decreased with $\mathrm{N}$ addition within three fractions as a result of exogenous $\mathrm{N}$ supply. Nitrogen addition decreased the DOC: AP ratio in large macroaggregates and microaggregates which might induce microbial $\mathrm{C}$ limitation relative to $\mathrm{P}$. Nitrogen addition significantly decreased the exchangeable $\mathrm{Ca}: \mathrm{Mg}$ ratio within macroaggregates purportedly due to preferential leaching of exchangeable $\mathrm{Ca}$ under soil acidification as developed with $\mathrm{N}$ addition. Within three soil aggregate classes, a significant increase in the available $\mathrm{Fe}: \mathrm{Mn}$ ratio might cause plant Fe deficiency and Mn toxicity as affected by ecosystem $\mathrm{N}$ enrichment. Changes in the ratios of available elements among soil fractions that are responsible for different nutrient retention and cycling processes will cause nutrient imbalance, affect plant and microbial nutrient acquisition and chemical composition, and influence ecosystem productivity and health.

\section{Data availability}

Data are available at https://datadryad.org/resource/doi:10. 5061/dryad.333f1.

Author contributions. Yong Jiang and Zhuwen Xu designed the experiment; Jinfei Yin, Heyong Liu, and Ruzhen Wang carried them out. Xue Feng helped to do the laboratory analyses. Ruzhen Wang prepared the manuscript with contributions from all authors. 
Acknowledgements. This work was financially supported by the National Key Research and Development Program of China (2016YFC0500707) and the National Natural Science Foundation of China (41371251).

Edited by: P. Pereira

Reviewed by: three anonymous referees

\section{References}

Aciego Pietri, J. C. and Brookes, P. C.: Nitrogen mineralisation along a $\mathrm{pH}$ gradient of a silty loam UK soil, Soil Biol. Biochem., 40, 797-802, 2008.

Albrecht, W. A.: The Albrecht papers, Vol. 1: Foundation concepts, Acres USA, Kansas City, 1975.

Amezketa, E.: Soil aggregate stability: a review, J. Sustain. Agr, 14, 83-151, 1999.

Baker, J. M., Ochsner, T. E., Venterea, R. T., and Griffis, T. J.: Tillage and soil carbon sequestration - What do we really know?, Agr. Ecosyst. Environ., 118, 1-5, 2007.

Bear, F. E., Prince, A. L., Toth, S. J., and Purvis, E. R.: Magnesium in plants and soil, Bull. 760, New Jersey Agric. Exp. Stn., New Brunswick, 1951.

Beniston, J. W., Lal, R., and Mercer, K. L.: Assessing and managing soil quality for urban agriculture in a degraded vacant lot soil, Land Degrad. Dev., 27, 996-1006, 2016.

Buol, S. W., Southard, R. J., Graham, R. C., and McDaniel, P. A.: Soil genesis and classification, John Wiley \& Sons, 2011.

Cerdà, A., Morera, A. G., and Bodí, M. B.: Soil and water losses from new citrus orchards growing on sloped soils in the western Mediterranean basin, Earth Surf. Proc. Land., 34, 1822-1830, 2009.

Chen, Y., Xu, Z., Hu, H., Hu, Y., Hao, Z., Jiang, Y., and Chen, B.: Responses of ammonia-oxidizing bacteria and archaea to nitrogen fertilization and precipitation increment in a typical temperate steppe in Inner Mongolia, Appl. Soil Ecol., 68, 36-45, 2013.

Cleveland, C. C. and Liptzin, D.: C: $\mathrm{N}: \mathrm{P}$ stoichiometry in soil: is there a "Redfield ratio" for the microbial biomass?, Biogeochemistry, 85, 235-252, 2007.

Creamer, C. A., Filley, T. R., Boutton, T. W., Oleynik, S., and Kantola, I. B.: Controls on soil carbon accumulation during woody plant encroachment: Evidence from physical fractionation, soil respiration, and $\delta^{13} \mathrm{C}$ of respired $\mathrm{CO}_{2}$, Soil Biol. Biochem., 43, 1678-1687, 2011.

de Oliveira, S. P., de LaCerdà, N. B., Blum, S. C., Escobar, M. E. O., and de Oliveira, T. S.: Organic Carbon and Nitrogen Stocks in Soils of Northeastern Brazil Converted to Irrigated Agriculture, Land Degrad. Dev., 26, 9-21, 2015.

Dijkstra, P., Ishizu, A., Doucett, R., Hart, S. C., Schwartz, E., Menyailo, O. V., and Hungate, B. A.: ${ }^{13} \mathrm{C}$ and ${ }^{15} \mathrm{~N}$ natural abundance of the soil microbial biomass, Soil Biol. Biochem., 38, 3257-3266, 2006.

Dontsova, K. M. and Norton, L. D.: Clay dispersion, infiltration, and erosion as influenced by exchangeable $\mathrm{Ca}$ and $\mathrm{Mg}$, Soil Sci., 167, 184-193, 2002.

Dorodnikov, M., Blagodatskaya, E., Blagodatsky, S., Marhan, S., Fangmeier, A., and Kuzyakov, Y.: Stimulation of microbial ex- tracellular enzyme activities by elevated $\mathrm{CO}_{2}$ depends on soil aggregate size, Glob. Change Biol., 15, 1603-1614, 2009.

Du, Z., Ren, T., Hu, C., and Zhang, Q.: Transition from intensive tillage to no-till enhances carbon sequestration in microaggregates of surface soil in the North China Plain, Soil Till. Res., 146, 26-31, 2015.

Elser, J. J., Fagan, W. F., Kerkhoff, A. J., Swenson, N. G., and Enquist, B. J.: Biological stoichiometry of plant production: metabolism, scaling and ecological response to global change, New Phytol., 186, 593-608, 2010.

Fonte, S. J., Nesper, M., Hegglin, D., Velásquez, J. E., Ramirez, B., Rao, I. M., Bernasconi, S. M., Bünemann, E. K., and Frossard, E.: Pasture degradation impacts soil phosphorus storage via changes to aggregate-associated soil organic matter in highly weathered tropical soils, Soil Biol. Biochem., 68, 150-157, 2014.

Gunina, A. and Kuzyakov, Y.: Pathways of litter C by formation of aggregates and SOM density fractions: implications from ${ }^{13} \mathrm{C}$ natural abundance, Soil Biol. Biochem., 71, 95-104, 2014.

Han, X., Sistla, S. A., Zhang, Y., Lü, X., and Han, X.: Hierarchical responses of plant stoichiometry to nitrogen deposition and mowing in a temperate steppe, Plant Soil, 382, 175-187, 2014.

Heffernan, J. B. and Fisher, S. G.: Plant-microbe interactions and nitrogen dynamics during wetland establishment in a desert stream, Biogeochemistry, 107, 379-391, 2012.

Heil, R. D. and Buntley, G. J.: A comparison of the characteristics of the ped faces and ped interiors in the B horizon of a Chestnut soil, Soil Sci. Soc. Am. J., 29, 583-587, 1965.

Hodges, S. C.: Soil fertility basics, Soil Science Extension, North Carolina State University, 2010.

Hogan, E. J., Minnullina, G., Smith, R. I., and Crittenden, P. D.: Effects of nitrogen enrichment on phosphatase activity and nitrogen: phosphorus relationships in Cladonia portentosa, New Phytol., 186, 911-925, 2010.

Jastrow, J. D., Amonette, J. E., and Bailey, V. L.: Mechanisms controlling soil carbon turnover and their potential application for enhancing carbon sequestration, Clim. Change, 80, 5-23, 2007.

Kang, L., Han, X., Zhang, Z., and Sun, O. J.: Grassland ecosystems in China: review of current knowledge and research advancement, Philos. T. R. Soc. B., 362, 997-1008, 2007.

Kemmitt, S. J., Wright, D., Goulding, K. W., and Jones, D. L.: pH regulation of carbon and nitrogen dynamics in two agricultural soils, Soil Biol. Biochem., 38, 898-911, 2006.

Katou, H.: A pH-dependence implicit formulation of cation-and anion-exchange capacities of variable-charge soils, Soil Sci. Soc. Am. J., 66, 1218-1224, 2002.

Kopittke, P. M. and Menzies, N. W.: A review of the use of the basic cation saturation ratio and the "ideal" soil, Soil Sci. Soc. Am. J., 71, 259-265, 2007.

Lajtha, K. and Bloomer, S. H.: Factors affecting phosphate sorption and phosphate retention in a desert ecosystem, Soil Sci., 146, 160-167, 1988.

Liu, L. and Greaver, T. L.: A global perspective on belowground carbon dynamics under nitrogen enrichment, Ecol. Lett., 13, 819-828, 2010.

Liu, S., Schleuss, P. M., and Kuzyakov, Y.: Carbon and Nitrogen Losses from Soil Depend on Degradation of Tibetan Kobresia Pastures, Land Degrad. Dev., doi:10.1002/ldr.2522, in press, 2016. 
Liu, W., Zhang, Z., and Wan, S.: Predominant role of water in regulating soil and microbial respiration and their responses to climate change in a semiarid grassland, Glob. Change Biol., 15, 184-195, 2009.

Lombini, A., Llugany, M., Poschenrieder, C., Dinelli, E., and Barceló, J.: Influence of the $\mathrm{Ca} / \mathrm{Mg}$ ratio on $\mathrm{Cu}$ resistance in three Silene armeria ecotypes adapted to calcareous soil or to different, Ni-or Cu-enriched, serpentine sites, J. Plant Physiol., 160, 14511456, 2003.

Lu, X., Mao, Q., Gilliam, F. S., Luo, Y., and Mo, J.: Nitrogen deposition contributes to soil acidification in tropical ecosystems, Glob. Change Biol., 20, 3790-3801, 2014.

Lü, L., Wang, R., Liu, H., Yin, J., Xiao, J., Wang, Z., Zhao, Y., Yu, G., Han, X., and Jiang, Y.: Effect of soil coarseness on soil base cations and available micronutrients in a semi-arid sandy grassland, Solid Earth, 7, 549-556, doi:10.5194/se-7-549-2016, 2016.

Lü, X., Reed, S., Yu, Q., He, N., Wang, Z., and Han, X.: Convergent responses of nitrogen and phosphorus resorption to nitrogen inputs in a semiarid grassland, Glob. Change Biol., 19, 2775-2784, 2013.

Lucas, R. W., Klaminder, J., Futter, M. N., Bishop, K. H., Egnell, G., Laudon, H., and Högberg, P.: A meta-analysis of the effects of nitrogen additions on base cations: implications for plants, soils, and streams, Forest Ecol. Manag., 262, 95-104, 2011.

Loew, O.: Uber die physiolgischen funkton der kalzium- und magnesia- salze in planzen organisms, Flora, 75, 368-394, 1892.

Lynch, J. P. and Clair, S. B. S.: Mineral stress: the missing link in understanding how global climate change will affect plants in real world soils, Field Crop. Res., 90, 101-115, 2004.

Malhi, S. S., Nyborg, M., and Harapiak, J. T.: Effects of long-term $\mathrm{N}$ fertilizer-induced acidification and liming on micronutrients in soil and in bromegrass hay, Soil Till. Res., 48, 91-101, 1998.

McLeod, S.: Micro-distillation unit for use in continuous flow analyzers, Its construction and use in determination of ammonia and nitrate in soils, Anal. Chim. Acta, 266, 107-112, 1992.

Menge, D. N. and Field, C. B.: Simulated global changes alter phosphorus demand in annual grassland, Glob. Change Biol., 13, 2582-2591, 2007.

Mikha, M. M. and Rice, C. W.: Tillage and manure effects on soil and aggregate-associated carbon and nitrogen, Soil Sci. Soc. Am. J., 68, 809-816, 2004.

Moreno, M. T., Carmona, E., de Santiago, A., Ordovás, J., and Delgado A.: Olive Husk Compost Improves the Quality of Intensively Cultivated Agricultural Soils, Land Degrad. Dev., 27, 449459, 2016.

Murphy, J. and Riley, J. P.: A modified single solution method for the determination of phosphate in natural waters, Anal. Chim. Acta, 27, 31-36, 1962.

Neff, J., Townsend, A. R., Gleixner, G., Lehman, S., Turnbull, J., and Bowman, W.: Variable effects of nitrogen additions on the stability and turnover of soil carbon, Nature, 419, 915-917, 2002.

Novara, A., Keesstra, S., Cerdà, A., Pereira, P., and Gristina, L.: Understanding the role of soil erosion on $\mathrm{CO}_{2}-\mathrm{C}$ loss using ${ }^{13} \mathrm{C}$ isotopic signatures in abandoned Mediterranean agricultural land, Sci. Total Environ., 550, 330-336, 2016.

Ochoa-Cueva, P., Fries, A., Montesinos, P., Rodríguez-Díaz, J. A., and Boll, J.: Spatial estimation of soil erosion risk by land-cover change in the Andes of Southern Ecuador, Land Degrad. Dev., 26, 565-573, 2015.

Olsen, S. R., Watanabe, F. S., Cosper, H. R., Larson, W. E., and Nelson, L. B.: Residual phosphorus availability in long-term rotations on calcareous soils, Soil Sci., 78, 141-152, 1954.

Oorts, K., Vanlauwe, B., and Merckx, R.: Cation exchange capacities of soil organic matter fractions in a Ferric Lixisol with different organic matter inputs, Agr. Ecosyst. Environ., 100, 161-171, 2003.

Pereira, P., Cerdà, A., Lopez, A. J., Zavala, L. M., Mataix-Solera, J., Arcenegui, V., Misiune, I., Keesstra, S., and Novara. A.: Shortterm vegetation recovery after a grassland fire in Lithuania: the effects of fire severity, slope position and aspect, Land Degrad. Dev., 27, 1523-1534, doi:10.1002/1dr.2498, 2016.

Piccolo, A.: The supramolecular structure of humic substances, Soil Sci., 166, 810-832, 2001.

Reich, P. B., Tjoelker, M. G., Pregitzer, K. S., Wright, I. J., Oleksyn, J., and Machado, J. L.: Scaling of respiration to nitrogen in leaves, stems and roots of higher land plants, Ecol. Lett., 11, 793801, 2008.

Rodrigo Comino, J., Iserloh, T., Lassu, T., Cerdà, A., Keesstra, S. D., Prosdocimi, M., Brings, C., Marzen, M., Ramos, M. C., Senciales, J .M., Ruiz Sinoga, J. D., Seeger, M., and Ries, J. B.: Quantitative comparison of initial soil erosion processes and runoff generation in Spanish and German vineyards, Sci. Total Environ., 565, 1165-1174, 2016.

Rogovska, N. P., Blackmer, A. M., and Mallarino, A. P.: Relationships between soybean yield, soil $\mathrm{pH}$, and soil carbonate concentration, Soil Sci. Soc. Am. J., 71, 1251-1256, 2007.

Sardans, J. and Peñuelas, J.: The role of plants in the effects of Global Change on nutrient availability and stoichiometry in the plant-soil system, Plant Physiol., 160, 1741-1761, 2012.

Schmidt, E. L.: Nitrification in Soil, in: , Nitrogen in Agricultural Soils, edited by: Stevenson, F. J., Madison, WI, USA, American Society of Agronomy, 1982.

Six, J. and Paustian, K.: Aggregate-associated soil organic matter as an ecosystem property and a measurement tool, Soil Biol. Biochem., 68, A4-A9, 2014.

Somers, I. I. and Shive, J. W.: The iron-manganese relation in plant metabolism, Plant Physiol., 17, 582-602, 1942.

Tanaka, A. and Navasero, S. A.:. Interaction between iron and manganese in the rice plant, Soil Sci. Plant Nutr., 12, 29-33, 1966.

Tian, Q., Liu, N., Bai, W., Li, L., Chen, J., Reich, P. B., Yu, Q., Guo, D. L., Smith, M. D., Knapp, A. K., Cheng, W., Lu, P., Gao, Y., Yang, A., Wang, T., Li, X., Wang, Z., Ma, Y., Han, X., and Zhang, W.: A novel soil manganese mechanism drives plant species loss with increased nitrogen deposition in a temperate steppe, Ecology, 97, 65-74, 2016.

Tian, Q.-Y., Liu, N.-N., Bai, W.-M., Li, L.-H., and Zhang, W.-H.: Disruption of metal ion homeostasis in soils is associated with nitrogen deposition-induced species loss in an Inner Mongolia steppe, Biogeosciences, 12, 3499-3512, doi:10.5194/bg-123499-2015, 2015.

Treseder, K. K.: Nitrogen additions and microbial biomass: A metaanalysis of ecosystem studies, Ecol. Lett., 11, 1111-1120, 2008.

Tunesi, S., Poggi, V., and Gessa, C.: Phosphate adsorption and precipitation in calcareous soils: the role of calcium ions in solution and carbonate minerals, Nutr. Cycl. Agroecosys., 53, 219-227, 1999. 
Wang, R., Dungait, J. A., Creamer, C. A., Cai, J., Li, B., Xu, Z., Zhang, Y., Ma, Y., and Jiang, Y.: Carbon and nitrogen dynamics in soil aggregates under long-term nitrogen and water addition in a temperate steppe, Soil Sci. Soc. Am. J., 79, 527-535, 2015a.

Wang, R., Dorodnikov, M., Yang, S., Zhang, Y., Filley, T. R., Turco, R. F., Zhang, Y., Xu, Z., Li, H., and Jiang, Y.: Responses of enzymatic activities within soil aggregates to 9-year nitrogen and water addition in a semi-arid grassland, Soil Biol. Biochem., 81, 159-167, 2015b.

Wang, R., Creamer, C. A., Wang, X., He, P., Xu, Z., and Jiang, Y.: The effects of a 9 -year nitrogen and water addition on soil aggregate phosphorus and sulfur availability in a semi-arid grassland, Ecol. Indic., 61, 806-814, $2016 \mathrm{a}$.

Wang, R., Dungait, J. A., Buss, H. L., Yang, S., Zhang, Y., $\mathrm{Xu}, \mathrm{Z}$., and Jiang, Y.: Base cations and micronutrients in soil aggregates as affected by enhanced nitrogen and water inputs in a semi-arid steppe grassland, Sci. Total Environ., doi:10.1016/j.scitotenv.2016.09.018, in press, 2016b.

Wei, C., Yu, Q., Bai, E., Lü, X., Li, Q., Xia, J., Kardol, P., Liang, W., Wang, Z., and Han, X.: Nitrogen deposition weakens plantmicrobe interactions in grassland ecosystems, Glob. Change Biol., 19, 3688-3697, 2013.

Wiesmeier, M., Steffens, M., Mueller, C. W., Kölbl, A., Reszkowska, A., Peth, S., Horn, R., and Kögel-Knabner, I.: Aggregate stability and physical protection of soil organic carbon in semi-arid steppe soils, Eur. J. Soil Sci., 63, 22-31, 2012.

Wright, I. J.: Phosphorus sequestration in soil aggregates after longterm tillage and cropping, Soil Till. Res., 103, 406-411, 2009.

Wright, I. J., Reich, P. B., Westoby, M., Ackerly, D. D.,Baruch, Z., Bongers, F.,Cavender-Bares, J., Chapin, T., Cornelissen, J. H. C., Diemer, M., Flexas, J., Garnier, E., Groom, P.K., Gulias, J., Hikosaka, K., Lamont, B. B., Lee, T., Lee, W., Lusk, C., Midgley, J. J., Navas, M.L., Niinemets, Ü., Oleksyn, J., Osada, N., Poorter, H., Poot, P., Prior, L., Pyankov, V. I., Roumet, C., Thomas, S. C., Tjoelker, M. G., Veneklaas, E. J., and Villar, R.: The worldwide leaf economics spectrum, Nature, 428, 821-827, 2004.
Wu, H., Wiesmeier, M., Yu, Q., Steffens, M., Han, X., and KögelKnabner, I.: Labile organic $\mathrm{C}$ and $\mathrm{N}$ mineralization of soil aggregate size classes in semiarid grasslands as affected by grazing management, Biol. Fertil. Soils, 48, 305-313, 2012.

Xu, Z., Wan, S., Ren, H., Han, X., Li, M. H., Cheng, W., and Jiang, Y.: Effects of water and nitrogen addition on species turnover in temperate grasslands in northern China, PloS ONE, 7, e39762, doi:10.1371/journal.pone.0039762, 2012.

Young, I. M. and Ritz, K.: Tillage, habitat space and function of soil microbes, Soil Till. Res., 53, 201-213, 2000.

Zhang, X. and Norton, L. D.: Effect of exchangeable Mg on saturated hydraulic conductivity, disaggregation and clay dispersion of disturbed soils, J. Hydrol., 260, 194-205, 2002.

Zhang, L., Unteregelsbacher, S., Hafner, S., Xu, X., Schleuss, P. M., Miehe, G., and Kuzyakov, Y.: Fate of Organic and Inorganic Nitrogen in Crusted and Non-Crusted Kobresia Grasslands, Land Degrad. Dev., doi:10.1002/ldr.2582, in press, 2016.

Zupanc, V., Kammerer, G., Grčman, H., Šantavec, I., Cvejić, R., and Pintar, M.: Recultivation of agricultural land impaired by construction of a hydropower plant on the Sava River, Slovenia, Land Degrad. Dev., 27, 406-415, 2016. 